\title{
Hypoxic response of two marine benthic communities
}

\author{
Hans C. Nilsson, Rutger Rosenberg
}

University of Göteborg, Kristineberg Marine Research Station, S-450 34 Fiskebäckskil, Sweden

\begin{abstract}
Benthic macrofauna communities were sampled with their 'undisturbed' sediments from 2 soft-bottom sites on the Swedish west coast. At one of the sites the top sediment had a positive redox potential (Expt 1) and at the other the sediment was comparatively more reduced close to the surface (Expt 2). The benthic communities at these 2 sites were each exposed to 3 treatments of oxygen concentrations: (1) normoxia (>8.0 $\mathrm{mg} \mathrm{l}^{-1},>90 \%$ oxygen saturation), (2) moderate hypoxia $\left(\sim 1.0 \mathrm{mg} \mathrm{l} \mathrm{l}^{-1}\right.$, $12 \%$ oxygen saturation) and (3) severe hypoxia ( $\sim 0.5 \mathrm{mg} \mathrm{l}^{-1}, 6 \%$ oxygen saturation). Redox potential profiles in the sediments showed a significant increase with time under normoxic conditions, whereas they showed an overall decline with time in moderate and severe hypoxia. The number of individuals and species at the 2 field sites did not differ significantly from corresponding numbers in the experimental normoxia (laboratory control) at the end of those experiments. In Expt 1 survival of the number of individuals was reduced in severe hypoxia compared to in moderate hypoxia and normoxia. The number of species was significantly reduced between all treatments. In Expt 2 community abundance and the number of species were significantly reduced in moderate and severe hypoxia compared to normoxia. Behaviour of dominant species is described: in general they left their position in the sediment (for Pectinaria koreni with their tubes) and occurred at the sediment surface in the moderate and severe hypoxic treatments. Comparison of the results of Expt 1 with those of Expt 2 suggests that the comparatively more reduced sediment in Expt 2 resulted in a greater negative response, implying the significance of sediment conditions for benthic macrofauna response to hypoxia.
\end{abstract}

KEY WORDS: Redox potential - Benthic macrofauna - Behaviour - Mysella bidentata - Amphiura filiformis Labidoplax buskii Echinocardium cordatum - Pectinaria koreni - Philine aperta $\cdot$ Nephtys hombergi

\section{INTRODUCTION}

Seasonally dependent hypoxia or anoxia is today a world-wide problem in many stratified bottom waters (Officer et al. 1984, Rosenberg \& Loo 1988, Degobbis 1989). This problem has been accelerated with an increased input of nutrients during the last decades (Rosenberg 1985, Rosenberg et al. 1990). Benthic field studies have shown that an oxygen concentration of $<0.7 \mathrm{mg} \mathrm{l}^{-1}$ in bottom water, prevailing for several weeks, could reduce benthic macrofauna and significantly affect the structure of benthic communities (Rosenberg et al. 1992).

Experimental studies and field observations have shown a wide variation in hypoxic and anoxic tolerance of benthic species (Henriksson 1969, Theede et al. 1969, Jørgensen 1980, Rosenberg et al. 1991). Dif- ferences may also be found between related species and have been suggested to be a consequence of metabolic rate and feeding behaviour (Amphiura spp. and Abra spp.; Rosenberg et al. 1991) and of the ability to withstand hydrogen sulphide (Nereis spp.; Theede et al. 1973, Vismann 1990).

High concentrations of sulphide (up to $10 \mathrm{mM}$ ) may be found at a few $\mathrm{mm}$ or $\mathrm{cm}$ depth in marine sediments (Fenchel \& Riedel 1970), and in reduced conditions the sulphide zone may extend up into the sediment-water interface and affect the fauna in the top sediment. The different tolerance of species to $\mathrm{H}_{2} \mathrm{~S}$, anoxia or hypoxia makes them react in various ways to avoid or to cope with such conditions (Shick 1976, Jørgensen 1980, Meyers et al. 1988, Rosenberg et al. 1991, Vismann 1991, Miron \& Kristensen 1993). 
Declines in bottom-water oxygen concentrations have been shown to push the redox potential discontinuity closer to the sediment surface both in areas with seasonally dependent hypoxia (Jørgensen 1980) and in permanently stagnant water bodies (Rosenberg et al. 1977, Pearson \& Stanley 1979). However, redox potential measurements do not show how deep dissolved oxygen penetrates into the sediment. Dissolved oxygen generally extends only a few $\mathrm{mm}$ beneath the sediment surface (Revsbech et al. 1980, Revsbech \& Jargensen 1986).

Little is known about the interaction between sediment chemistry and faunal reactions during hypoxic conditions. In this study we report on benthic macrofaunal response to hypoxia in 2 different benthic communities. Macrofaunal survival and behaviour were studied in relation to different oxygen concentrations in the water and changing redox potentials in the sediment in their natural sediment. This is to our knowledge the first time that such hypoxic experiments have been conducted with 'undisturbed' benthic infaunal communities. In the first experiment the fauna was collected at a site where the top sediment had a positive redox potential. In the second experiment the sediment was comparatively more reduced close to the sediment surface and black below.

\section{MATERIALS AND METHODS}

Expt 1. A total of 24 'undisturbed' HAPS cores (0.012 $\mathrm{m}^{2}$; Kanneworff \& Nicolaisen 1973) with fauna and sediment were taken at $28.5 \mathrm{~m}$ depth (below the halocline) in the outer part of Brofjorden, western

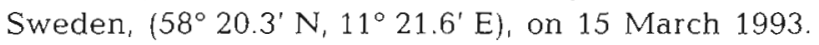
Eighteen of these cores were randomly divided into
Table 1. Treatment and experimental conditions in Expts 1 ( $9 \mathrm{~d}, 11$ to $13^{\circ} \mathrm{C}, 33$ to $\left.34 \mathrm{psu}\right)$ and $2\left(7 \mathrm{~d}, 17\right.$ to $19^{\circ} \mathrm{C}, 25$ to 26 psu): mean oxygen concentration \pm SD between Days 13 and 21 in Expt 1 and between Days 8 and 14 in Expt 2 (see Fig. 1)

\begin{tabular}{|lrrr|}
\hline Treatment & \multicolumn{3}{c}{ Mean oxygen concentration } \\
& $\mathrm{mgl} \mathrm{l}^{-1} \pm \mathrm{SD}$ & $\%$ Air sat & $\mathrm{kPa}$ \\
\hline Expt 1 & & & \\
$\quad$ Normoxia & $8.2 \pm 0.2$ & 92 & 19.5 \\
$\quad$ Moderate hypoxia & $1.1 \pm 0.1$ & 12 & 2.6 \\
Severe hypoxia & $0.6 \pm 0.2$ & 7 & 1.4 \\
Expt 2 & & & \\
Normoxia & $8.2 \pm 0.1$ & 100 & 20.7 \\
$\quad$ Moderate hypoxia & $1.0 \pm 0.4$ & 12 & 2.6 \\
Severe hypoxia & $0.5 \pm 0.2$ & 6 & 1.3 \\
\hline
\end{tabular}

6 PVC aquaria $(56 \times 36 \times 40 \mathrm{~cm}), 3$ in each, and 6 cores were used as a field control. These latter cores were immediately sieved through a $1 \mathrm{~mm}$ sieve and the remains were put in $70 \%$ ethanol for later sorting. At sampling, oxygen, temperature and salinity were $7.8 \mathrm{mg} 1^{-1}, 4.8^{\circ} \mathrm{C}$ and 33 psu.

Two aquaria were randomly selected for each of the 3 oxygen treatments: normoxia $\left(\sim 8.2 \mathrm{mg}^{-1}\right.$, control), moderate hypoxia $\left(\sim 1.0 \mathrm{mg} \mathrm{l}^{-1}\right)$ and severe hypoxia $\left(\sim 0.5 \mathrm{mg}^{-1}\right)$ (Table 1$)$. The total experimental time was $21 \mathrm{~d}$ and hypoxic conditions were reached after $13 \mathrm{~d}$ (Fig. 1). All aquaria were filled with $50 \mathrm{I}$ unfiltered deep-sea water and $10 \%$ of the water was exchanged every week. Water was circulated by an external pump at $3.01 \mathrm{~min}^{-1}$ in the hypoxic aquaria or constantly bubbled with air in the normoxic aquaria. The water surface was covered with a floating plastic cover to decrease diffusion of oxygen. Oxygen concentration was monitored 3 times daily with a Winkler calibrated Wtw oxygen meter (Oxi 196) about $1 \mathrm{~cm}$ above the sediment surface. Every 12 h the faunal behaviour was observed at the sediment surface, and oxygen concentrations were regulated by bubbling with pure $\mathrm{N}_{2}$ gas or with air in the hypoxic aquaria. The experiment was performed in darkness and no extra food was added.

Redox potential (Eh) was measured on 3 occasions (Fig 1 ) in all cores, with a platinum electrode $\varnothing 1.5 \mathrm{~mm}$ (Microelectrodes, Inc. MI-800-412) from the sediment surface down to $3 \mathrm{~cm}$ sediment depth. The electrode was mounted on a stand and slowly moved down in $0.5 \mathrm{~cm}$ steps; readings were done after $30 \mathrm{~s}$. Methods and calculations of Eh were done after Fenchel (1969).
Fig. 1. Mean sea-water oxygen concentrations in the 3 treatments: normoxia $(\Delta)$, moderate hypoxia (o) and severe hypoxia (a) in Expts 1 and 2. Horizontal lines (-.) outline the attainable oxygen treatment concuntrations and arrows ( $)$ indicate times of redox potential readings 
Organic content of the sediment was estimated as loss of ignition after drying in $70^{\circ} \mathrm{C}$ to constant weight and subsequent burning for $3 \mathrm{~h}$ in $500^{\circ} \mathrm{C}$.

Expt 2. Expt 2 (Table 1) followed the procedure described for Expt 1 except for the following. Forty HAPS cores were sampled at $10.5 \mathrm{~m}$ depth (above the halocline) south of Lysekil fishing port $\left(58^{\circ} 16.5^{\prime} \mathrm{N}, 11^{\circ} 26.8^{\prime} \mathrm{E}\right)$ on $10 \mathrm{Sep}$ tember 1993 . Thirty of these cores were randomly divided into 6 PVC aquaria, 5 in each, and 10 cores were used as a field control. At sampling, oxygen, temperature and salinity were $8.2 \mathrm{mg} \mathrm{l}^{-1}$, $14.2^{\circ} \mathrm{C}$ and 26 psu. Aquaria were filled with $50 \mathrm{l}$ unfiltered surface $(6 \mathrm{~m})$ sea water. The experiment lasted for $14 \mathrm{~d}$ and hypoxic conditions were reached after 8 d (Fig. 1). Redox recordings were done from $0.5 \mathrm{~cm}$ above the sediment surface down to $3 \mathrm{~cm}$ in the sediment at $0.5 \mathrm{~cm}$ intervals.

Calculation of redox profile. To determine changes of the 'redox profiles' with time (see Fig. 2), the area between the profile and the $y$-axis was assessed with a computer-aided graphic method (NIH image 1.50 for Macintosh computers).

Statistics. Differences in abundance, number of species and temporal differences of the 'redox profile' were analysed using nested 1-way ANOVA, where cores were nested in aquaria (Underwood 1981). Analyses for differences in organic content between field control and treatments were done with a 1-way ANOVA. Multiple comparisons of means were made with a StudentNewman-Keuls (SNK) test. Homogeneity of variances was examined using Cochran's C-test (Snedecor \& Cochran 1967) and heterogeneity was removed by $x^{0.5}$ transformation.

\section{RESULTS}

\section{Sediment surface}

At the end of the experiments no significant [ANOVA, $p>0.25$, degrees of freedom $(\mathrm{df})=3,4$ ] differences were found in the loss of ignition between the field control and any treatment in either of the 2 experiments. In the hypoxic treatments in Expt 1 the sediment surface had signs of activity from animals escap-
Expt 1

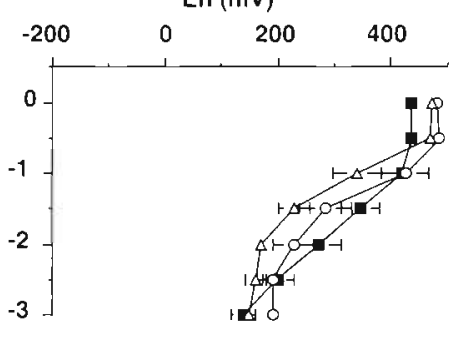

Normoxia

\section{Expt 2}
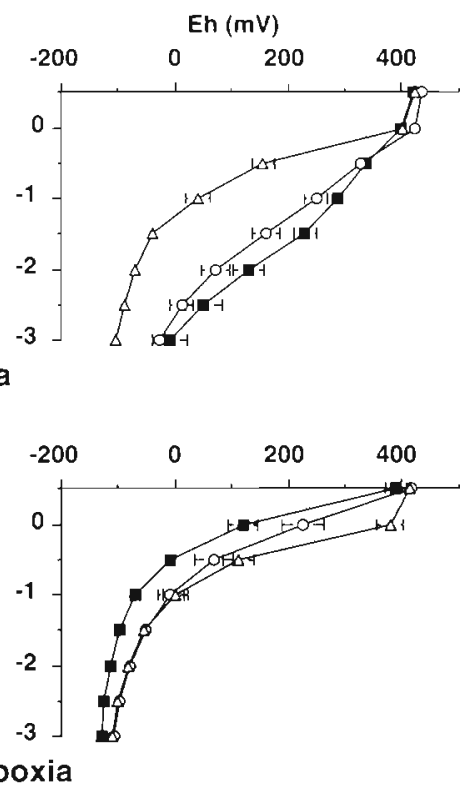

Moderate hypoxia
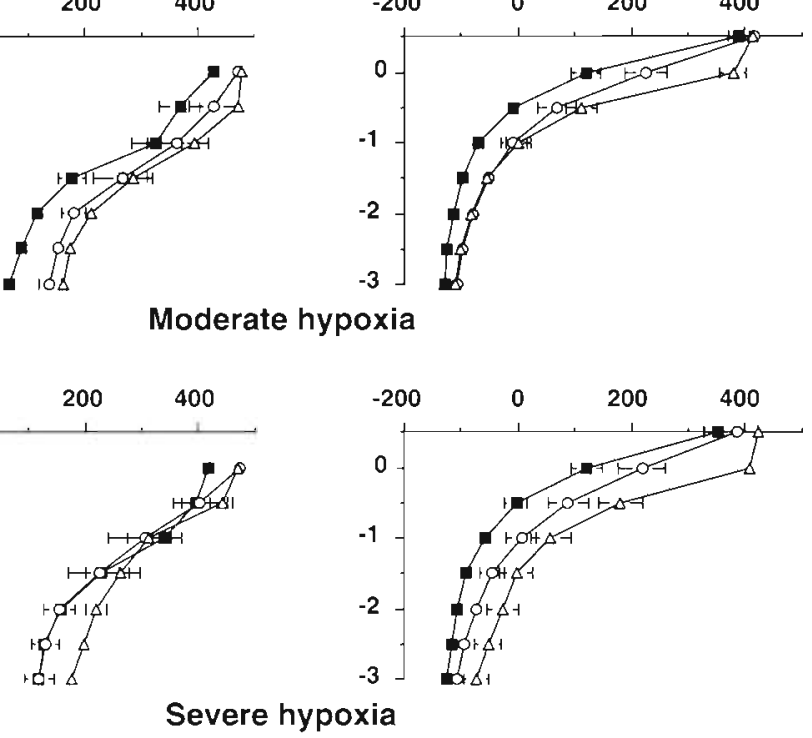

Severe hypoxia

. Mean redox potential $\pm \mathrm{SE}$ in the 3 treatments in Expts $1(n=6)$ and 2 $(\mathrm{n}=10)$. Three recordings are shown in each graph, first recording before experimental start $(\Delta)$, second recording when hypoxic conditions were obtained $(0)$, and third recording before finishing the experiments ( $)$, as indicated in Fig. 1

ing the sediment. At the end of Expt 2 all cores in hypoxic treatments were covered with Beggiatoa spp. mats, with up to between 50 and $100 \%$ of the area covered. No notable changes were observed at the sediment surface in the normoxic treatment in either Expt 1 or Expt 2.

\section{Redox potential}

Fig. 2 shows the depth profiles of the mean redox potentials $\pm \mathrm{SE}$ in the 2 experiments for each treatment on the 3 reading occasions. The redox profiles increased in normoxia and decreased in moderate and severe hypoxia with time in both experiments. Changes in 'redox potential' over time (between recordings 1 and 3) was significantly (SNK, p $<0.05$, $\mathrm{df}=2,3$ ) different between normoxia and both hypoxic treatments in Expts 1 and 2. 


\section{Field control}

The sediment from Brofjorden used in Expt 1 was a silty mud with rather high loss of ignition, $10 \%$. The benthic macrofauna was numerically dominated by the bivalve Mysella bidentata $\left(37 \%, 850\right.$ ind. $\mathrm{m}^{-2}$ ) and the ophiuroid Amphiura filiformis $\left(14 \%, 316\right.$ ind. $\left.\mathrm{m}^{-2}\right)$, followed by Amphiura chiajei, the polychaetes Diplocirrus glaucus, Nephtys incisa, Artacama proboscidea and Pholoe baltica, and the holothuroidean Labidoplax buskii, each making up about 2 to $5 \%$ of the abundance. In total the 6 field control cores contained 165 specimens divided among 22 species, mostly polychaetes.

In the field control sample from Lysekil fish port used in Expt 2, loss of ignition was 6\%. The sediment was unconsolidated muddy clay smelling of $\mathrm{H}_{2} \mathrm{~S}$. The benthic community was highly dominated by 4 species, the echinoid Echinocardium cordatum $(44 \%, 408$ ind. $\left.\mathrm{m}^{-2}\right)$, the polychaete Pectinaria koreni $(26 \%, 242$ ind. $\mathrm{m}^{-2}$ ), the opistobranch Philine aperta $(17 \%, 158$ ind. $\mathrm{m}^{-2}$ ) and the polychaete Nephtys hombergii $16 \%$ 50 ind. $\mathrm{m}^{-2}$ ). The 10 cores contained a total of 112 specimens divided among 7 species. In neither total abundance nor in number of species were significant (ANOVA, $p>0.25, \mathrm{df}=1,2$ ) differences noted between the field controls and the normoxic treatments (control) at the end of Expts 1 and 2 (Fig. 3).

\section{Survival}

In Expt 1 a significant (SNK, $p<0.05$, df $=2,3$ ) decrease in total abundance was recorded in severe hypoxia compared with normoxia and moderate hypoxia. However between the 2 latter treatments no significant (SNK, $p>0.05, \mathrm{df}=2,3$ ) difference was observed in total abundance (Fig. 3). Number of species was significantly ( $\mathrm{SNK}, \mathrm{p}<0.05$, df $=2,3$ ) reduced between all treatments, from a mean of 9.8 species in normoxia, to 6.8 species in moderate hypoxia and to 3.5 in severe hypoxia. Amphiura filiformis, Mysella bidentata, Artacama proboscidea and most other species of Polychaeta showed no or little mortality in moderate hypoxia. In severe hypoxia the abundance of each species was reduced by at least $35 \%$ compared to the control

In Expt 2 a significant (SNK, $p<0.05, \mathrm{df}=2,3$ ) decrease in total abundance and number of species was recorded for both hypoxic treatments compared with normoxia. However, no differences were observed between the hypoxic treatments. All Echinocardium cordatum died when exposed to hypoxia (both moderate and severe) and almost all Philine aperta left the cores (see below) or died on the
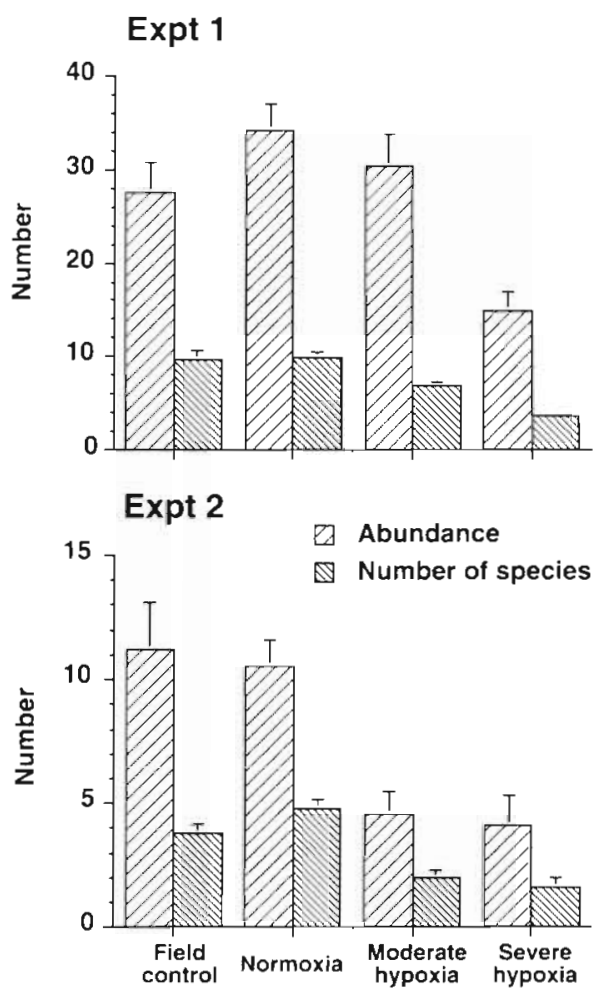

Fig. 3. Mean total abundance core ${ }^{-1}\left(0.012 \mathrm{~m}^{2}\right) \pm$ SE and mean no. of species core ${ }^{-1} \pm \mathrm{SE}$ in field control and the 3 treatments after finishing the experiments (Expt 1, n $=6$; Expt 2, n $=10$ )

sediment surface. Some specimens of Pectinaria koreni (10 to $15 \%$ ) and of Nephtys hombergii ( 12 to $17 \%$ ) died in the 2 hypoxic treatments. In normoxia no mortality was observed in these 4 species

\section{Behaviour}

The behaviour of Amphiura filiformis in the hypoxic treatments in Expt 1 differed from the individuals in normoxia when the oxygen saturation dropped below $22 \%$ (Fig. 4). They were all buried in the sediment up to that stage. In severe hypoxia half of the individuals had left the sediment when the water oxygen saturation reached $9.0 \%$ and all of them were on the sediment surface 5 d later. Large numbers of juvenile (<1.8 mm oral width) Amphiura spp. (maximum 16 ind. core ${ }^{-1}$ ) were observed on the sediment surface after the adult $A$. filiformis were found there. In moderate hypoxia, $38 \%$ of the adult $A$. filiformis were on the sediment surface at the end of the experiment. In normoxia all $A$. filiformis individuals showed suspensionfeeding behaviour in the water with 1 to 3 arms most of the time. No $A$. filiformis ( $n=40$, total number) were observed on the sediment surface in normoxia. 


\section{Moderate hypoxia}

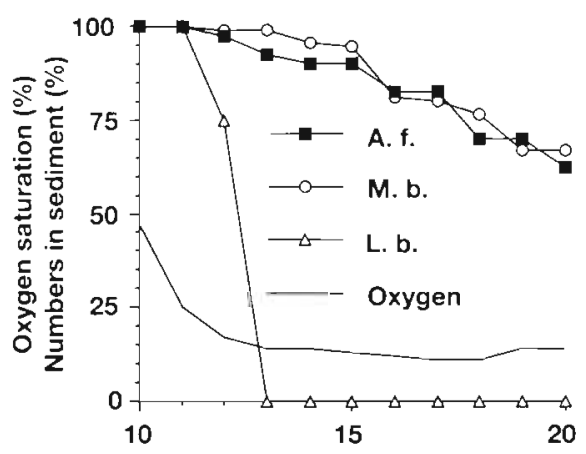

Severe hypoxia

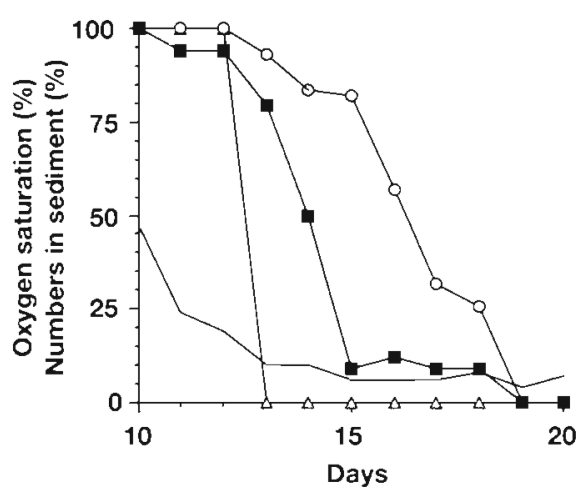

Fig. 4. Mean oxygen saturation in hypoxic treatments and observed percentage of Amphiura filiformis (A.f.), Mysella bidentala (M.b.) and Labidoplax buskii (L.b.) on the sediment surface during the hypoxic period in Expt 1

In the hypoxic aquaria, the first Mysella bidentata was observed on the sediment surface 0.5 to $2 \mathrm{~d}$ after the first Amphiura filiformis had emerged (Fig. 4). In moderate hypoxia proportionally the same numbers of $M$. bidentata left the sediment daily compared to $A$. filiformis. Bivalves in severe hypoxia emerged from the sediment at the same rate as $A$. filiformis, but with about $2 \mathrm{~d}$ delay. The first days after $M$. bidentata left the sediment they were active, crawling over the sediment or attaching themselves to the core walls. Only $2 \mathrm{M}$. bidentata were observed on the sediment surface in the normoxic treatment $(n=129)$.

In Expt 1 all Labidoplax buskii had left the sediment within $2 \mathrm{~d}$ in both hypoxic treatments as the oxygen saturation reached $16 \%$ (Fig. 4). In all observed cases these individuals left the sediment with their tentacles first. On the sediment surface they were idle and all died $(n=9)$ before the experiment was ended. In normoxia no specimens were observed on the sediment surface $(n=4)$

In Expt 2 the vertical position of Echinocardium cordatum in the sediment was recorded (Fig. 5). Most
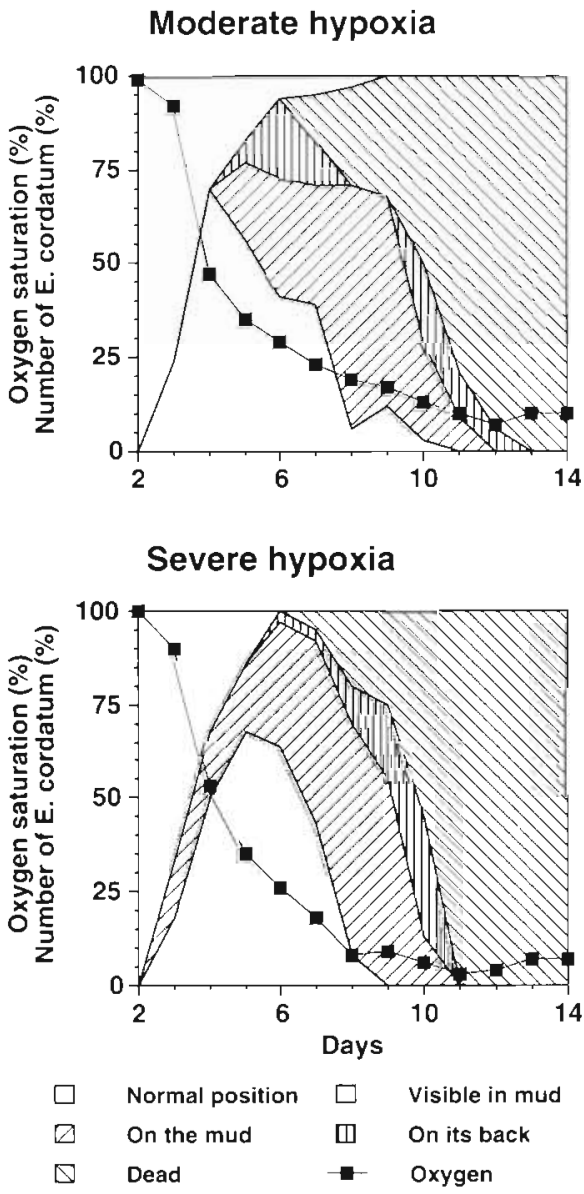

Fig. 5. Mean oxygen saturation in hypoxic treatments and the behaviour response of Echinocardium cordatum during the hypoxic period in Expt 2

urchins were small with a mean length of $10 \mathrm{~mm}$. No size-dependent behaviour or mortality was observed. All urchins left the sediment before moderate hypoxia or severe hypoxia occurred. At first the urchins were active crawling at or on the sediment surface. Before the urchins died they all turned over on their backs. In normoxia all urchins were burrowed into the sediment during the experiment except at one observation when 5 individuals were seen $(n=28)$.

The behaviour of Pectinaria koreni is illustrated in Fig. 6. These worms gradually left their normal position in the sediment with their tubes visible above the sediment surface in an erect position. From Day 8 to Day 14 (Fig. 6), as most of the tubes were protruding from the sediment surface, Beggiatoa spp. mats were found on several tube tips; however, the worms were still alive. Before the worms died the tubes with the worm fell and the animals seemed to try to leave the tubes. P. koreni appeared mainly in 2 size classes (cephalic diameter 1.5 and $3.0 \mathrm{~mm}$; Nicolaidou 1983), 


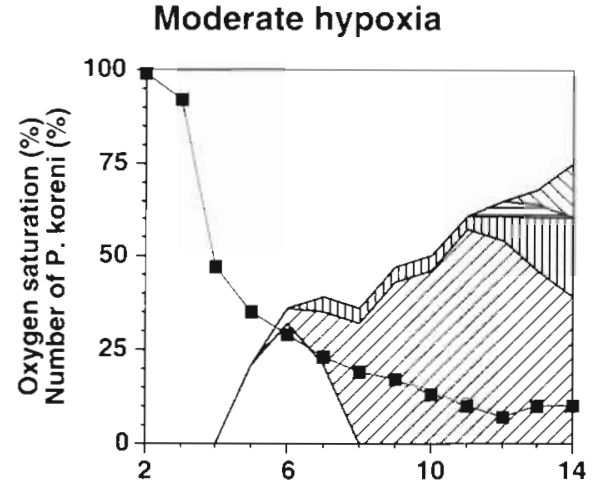

Severe hypoxia

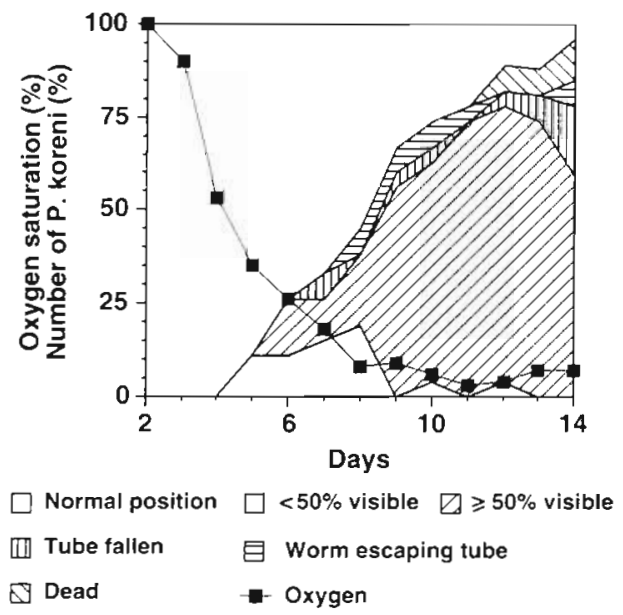

Fig. 6. Mean oxygen saturation in hypoxic treatments and the behaviour response of Pectinaria koreni during the hypoxic period in Expt 2

but there was no obvious correlation between size of the worm and behaviour or survival in hypoxia. In normoxia no worms left their normal position in the sediment ( $n=26$ ).

In both hypoxic treatments most Philine aperta escaped from the sediment and later even from the cores, but were found in the aquaria at the end of the experiment. In moderate hypoxia most of these individuals were still alive, but in severe hypoxia only 2 individuals were still alive. In normoxia we occasionally observed 1 individual on the sediment surface $(\mathrm{n}=13)$.

In Expt 2 Nephtys hombergii was the last macrofaunal species to leave the sediment, the first individuals appearing at the surface on Day 11. In moderate hypoxia $25 \%(n=24)$ of the individuals left the sediment during the last $4 \mathrm{~d}$ and $12 \%$ of these died before the experiment was ended. In severe hypoxia the corresponding numbers were 30 and $17 \%$, respectively $(\mathrm{n}=21)$. No swimming behaviour was observed after the worms had left the sediment in either moderate or severe hypoxia, and no worms were found at the bottom of the aquaria. In normoxia no worms were observed at the sediment surface $(n=16)$.

\section{DISCUSSION}

\section{Experimental design}

In this study we observed the response of the macrofauna during hypoxia in their natural sediments and in relation to changes of the redox profiles. There are at least 2 main problems with natural benthic microcosm experiments: (1) the gradual decline of 'natural' conditions during experimental procedure and (2) the variance between replicates could be significant because of patchiness of organisms and sediment characteristics. In this study the results from field control cores were used as a reference against the normoxic treatment (laboratory control) to detect significant changes in the faunal composition between the start of the experiment and the end. In both Expt 1 and 2 no significant faunal difference between the natural community (field control cores) and normoxia was recorded indicating that the experimental condition was close to 'natural'.

In this study the statistical analysis of differences in redox profiles was done after the area of the profile was graphically assessed to get a value for the whole measured profile. The nested design of the ANOVA allowed us to test the differences between replicates (Underwood 1981) and was used to test if the calculated areas were independent of the treatment effect. In both experiments the differences between replicates were low (ANOVA, $\mathrm{p}>0.40, \mathrm{df}=2,3$ ) when significant differences between treatments were observed. This verifies that the area was dependent on the treatments and the calculated area could be useful to detect differences in the redox potentials of sediment samples. Our conclusion of the experimental design in this study is that the natural benthic microcosm is a powerful tool to test the benthic response to hypoxia.

\section{Redox potential}

The vertical distribution of the redox potentials clearly shows the differences between the sediments used in Expts 1 and 2. The redox potential in the sediment followed similar trends in both experiments, increasing over time in normoxia and decreasing in hypoxia. The different oxygen concentrations in the water column and the likely difference in macrofaunal bioturbation and irrigation in the sediment are sug- 
gested as the 2 main components influencing the change of the redox potential in the sediment in these experiments.

In the normoxic treatment, the mean redox potentials increased in Expt 1 by $>100 \mathrm{mV}$ at 1 to $2 \mathrm{~cm}$ depth in the sediment, and in Expt 2 by up to $\sim 270 \mathrm{mV}$ at $1.5 \mathrm{~cm}$ depth. These increases of the mean redox potential in both experiments are likely to be an effect of increased activity of macrofauna pumping oxygenrich water into the sediment. It has been shown that large $(280 \mathrm{mV})$ periodical increases in redox potentials in otherwise anoxic sediments can occur as an effect of macrofaunal irrigation of the sediment (e.g. Callianassa subterranea; Forster \& Graf 1992).

In Expt 1 in moderate hypoxia the redox potential decreased over time between all recordings but in severe hypoxia no further decrease of the redox potential was registered after the second recording. Presence of fauna and their metabolic activity for a longer time in the sediment in the moderate hypoxic treatments compared to in the severe hypoxic treatments may explain this difference. Redox potential measurements in defaunated sediments have been shown to differ slightly over time (Fenchel 1969, Davis 1974). Fauna present in sediment during hypoxic periods is probably not able to notably oxidise the sediment because of lowered activity (bioturbation and irrigation) and because a shift from aerobic to anaerobic respiration will gradually occur in the sediment (de Zwaan \& Putzer 1985). A reduced irrigation down in the sediment will increase the chemical reduction in the sediment and probably be self-accelerating during hypoxic events, depending on when the fauna leaves the sediment.

In both the moderate and severe hypoxic treatments in Expt 2 the largest ( $>250 \mathrm{mV}$ ) decrease in the redox potentials as recorded at the sediment-water interface. This was probably a consequence of the extension of the sulphide system accompanying Beggiatoa spp. up towards the sediment surface.

\section{Survival and behaviour}

According to previous experimental hypoxic studies, both with 'undisturbed' sediments (Rosenberg et al. 1991) and where disturbed sediment has been included (Vismann 1990, Llanso' 1992b), most species leave the sediment in oxygen concentrations slightly higher than those inducing mortality of the species.

In Expt 1 the macrofaunal mortality rate was low in both normoxia and in moderate hypoxia, but rather high in severe hypoxia. The number of species was, however, significantly reduced in moderate hypoxia compared to in normoxia. Similar responses have been recorded in the field at a station in the Kattegat, Sweden, in the autumn, especially in 1988, when several species died during hypoxic conditions (Rosenberg et al. 1992). The experimental results in this study and the field study observations show that the structure of the benthic community could change during hypoxia and that the mortality may be species-specific and related to small differences in oxygen concentrations.

In Expt 1 a coupling between the behaviour of the 2 dominant species Mysella bidentata and Amphiura filiformis was observed in response to low oxygen concentrations in both hypoxic treatments (Fig. 4). This is probably a consequence of $M$. bidentata being associated with $A$. filiformis and occupying their burrows (Ockelmann \& Muus 1978). Thus, the bivalves probably left the sediment along with $A$. filiformis either as a result of their association, or because the oxygen conditions in the sediment became less suitable for them when A. filiformis had left. Ockelmann \& Muus (1978) also observed the behaviour of $M$. bidentata during hypoxia and found no behavioural response to oxygen concentrations when maintained at $>0.5 \mathrm{mg} \mathrm{l}^{-1}$. In the present experiments the first bivalves left the sediment at $1.7 \mathrm{mg} \mathrm{l}^{-1}$. In an earlier study by Rosenberg et al. (1991) half of the number of $A$. filiformis were found on the sediment surface at $0.6 \mathrm{mg}$ oxygen $\mathrm{l}^{-1}$ compared to at $0.8 \mathrm{mg} \mathrm{l}^{-1}$ in this study. The results in Expt 1 indicate that the response of the fauna during hypoxia could be dependent on interactions between species.

The first individuals of Echinocardium cordatum appeared on the sediment surface at the beginning of the hypoxic treatments in Expt 2 (Fig. 5), and the rest appeared successively over the following days. During this period the oxygen saturation declined from about 90 to $10 \%$ in both hypoxic treatments. Similar individual variation in behaviour response to declining oxygen saturations was observed in Pectinaria koreni (Fig. 6) and Nephtys hombergii (see below). These reactions may indicate variations in sediment and in addition be related to the position in the sediment and actual condition of these species. These lengthy reactions were in contrast to the 'threshold' responses observed for Amphiura filiformis in severe hypoxia in Expt 1 and in another similar experiment (Rosenberg et al. 1991).

Nephtys incisa in Expt 1 and $N$. hombergii in Expt 2 stayed in the sediment during hypoxia longer than other species. This may suggest that these species are particularly tolerant to hypoxia. This agrees with earlier observations of $N$. hombergii, which can survive at least $5 \mathrm{~d}$ in pure artificial anoxic seawater, not shifting metabolic pathways from aerobic to anaerobic before oxygen saturation decreases to $<12 \%$ (Schöttler 1982). In another experiment $50 \%$ of $N$. hombergii survived for $23 \mathrm{~d}$ in almost anaerobic conditions $\left(<0.2 \mathrm{mg} \mathrm{l}^{-1}\right)$, 
whereas $N$. ciliata survived 11 d in the same tests (Fallesen \& Jorgensen 1991). In Expt 2 the first individuals of $N$. hombergii left the sediment $3 \mathrm{~d}$ after mean oxygen saturation reached about 12 or $6 \%$. All individuals that left the sediment died 1 to $2 \mathrm{~d}$ later and were found dead on the sediment surface. There was no difference between the hypoxic treatments. In Expt $1 \mathrm{~N}$. incisa stayed in the sediment and was found in apparently good condition when the experiment was finished. The differences in response to hypoxia between $N$. incisa in Expt 1 and $N$. hombergii in Expt 2 suggest that the mortality of $N$. hombergii was induced by a combination of sediment conditions (sediment surface covered by Beggiatoa spp. mats) and low oxygen concentrations in Expt 2. This agrees with a study on the behaviour of Nereis spp., where those species showed a more rapid behavioural response when exposed to hypoxia and sulphide combined, compared to hypoxia alone (Vismann 1990). No individuals of Nephtys hombergii escaped from the cores in hypoxic aquaria in Expt 2 despite the fact that they can swim. The late response of the Nephtys species in leaving the sediment in the present experiments may be related to these species' avoidance of exposure to predators at the sediment surface, which has also been suggested for Nereis spp. by Vismann (1991).

In Expt 1 significant differences between moderate and severe hypoxia were observed in faunal survival and in changes of redox potential with time. No such faunal differences were observed in Expt 2. This implies that the community response is dependent both on the sediment conditions and on the oxygen concentration in the overlying water. The possible sulphide extension up to the sediment surface is dependent on sediment conditions (Fenchel \& Riedel 1970). Sulphide in hypoxic water has been shown to reduce macrobenthic survival more than in hypoxia alone, generally by about $20 \%$ in most taxa (Theede et al. 1969).

The different temperature in the 2 experiments may be one reason for different reactions of the fauna, and the higher temperature in Expt 2 is likely to have increased the rate of the chemical processes and reduced the sediment more rapidly than in Expt 1 We therefore suggest that the differences between Expts 1 and 2 in faunal response to moderate hypoxia were dependent on the different depths of the redox potential discontinuity (RPD; Fenchel \& Riedel 1970) and accompanying sulphide concentrations, and the differences in temperature.

Pearson \& Rosenberg (1978) developed models of benthic faunal distribution (number of species, abundance and biomass) in relation to gradients of sediment organic enrichment and water renewal rates. Data on redox potential measurements made during various degrees of organic enrichment, both in a sea loch in Scotland, UK, and in the laboratory, were later fitted to these models (Pearson \& Stanley 1979). These publications demonstrated gradients from totally anoxic sediments with no fauna at the highly enriched end to a rich and diverse fauna at the other end of the gradient where a positive redox potential was prevailing down to several centimetres.

Similarly, in a small bay in Sweden with a strong spatial gradient in sediment redox potential profiles, both meiofauna and macrofauna abundances were positively correlated with increasing positive redox potential distribution down in the sediments (Cato et al. 1980). Benthic macrofauna in the Baltic has been shown to move upwards in the sediment accompanying a seasonally emerging RPD (Ankar \& Jansson 1973). Thus, the effects of declining redox profiles on the fauna in the present investigation agree with the findings above, and we have also shown that low redox conditions in the top sediment may 'push' the animals out of the sediment.

Several recordings in natural sediments in the field have shown a clear seasonally related vertical distribution of the RPD layer (Ankar \& Jansson 1973, Rosenberg 1977, Pearson \& Stanley 1979). Such changes of reduced RPD profiles in the sediment are dependent on several factors such as high temperature, high organic enrichment, low water renewal and high total benthic respiration. When several of these factors occur simultaneously, the likelihood increases that the benthic infauna emerges upwards in the sediment and may eventually appear on the sediment surface

\section{Conclusions}

Based on the results in the present study and from benthic sampling in hypoxic areas in the Kattegat, Sweden (Rosenberg \& Loo 1988, Rosenberg et al. 1992), the Chesapeake Bay, USA (Llanso' 1992a), from SCUBA diving in the Limfjorden, Denmark (Jørgensen 1980) and from previous experiments (Rosenberg et al. 1991), the following can be concluded. (1) Most macrofaunal species leave the sediment in hypoxic oxygen concentrations slightly higher than those causing mortality. (2) Small but critical changes in hypoxic oxygen concentrations in the water could have a significant effect on the mortality of the total macrofauna. (3) Hypoxic periods could significantly reduce the number of species in a community without significantly affecting total abundance. (4) Similar hypoxic oxygen concentration in the bottom water could have different effects on both mortality and behaviour in different communities, induced by different sediment characteristics. (5) Interaction between species could be of significance in the behavioural response during hypoxia. 
Acknowledgements. We thank Susanne Eriksson, Alf Josefson, Leif Pihl, Bent Vismann and 3 anonymous reviewers for constructive criticism of the manuscript

\section{LITERATURE CITED}

Ankar, S., Jansson, B. O. (1973). Effects of an unusual natural temperature increase on a Baltic soft bottom community Mar. Biol. 18: 9-18

Cato, I., Olsson, I., Rosenberg, R. (1980). Recovery and decontamination of estuaries. In: Olausson, E., Cato, I. (eds.) Chemistry and biochemistry of estuaries. J. Wiley \& Sons, New York, p. 403-440

Davis, R. B. (1974). Tubificids alter profiles of redox potential and $\mathrm{pH}$ in profundal lake sediment. Limnol. Oceanogr. 19 : $342-346$

Degobbis, D. (1989). Increased eutrophication of the Northern Adriatic Sea. Mar. Pollut. Bull. 20:452-457

de Zwaan, A., Putzer, V. (1985). Metabolic adaptations of intertidal invertebrates to environmental hypoxia (a comparison of environmental anoxia to exercise anoxia). In Laverack, M. S. (ed.) Physiological adaptations of marine animals. The Company of Biologists, Cambridge, p. 33-62

Fallesen, G., Jørgensen, H. M. (1991). Distribution of Nephtys hombergii and $N$. ciliata (Polychaeta: Nephtyidae) in Ârhus Bay, Denmark, with emphasis on the effect of severe oxygen deficiency. Ophelia (Suppl.) 5: 443-450

Fenchel, T (1969). The ecology of marine microbenthos IV Structure and function of the benthic ecosystem, its chemical and physical factors and the microfauna communities with special reference to the ciliated protozoa. Ophelia 6 : $1-182$

Fenchel, T. M., Riedel, R. J. (1970). The sulfide system: a new biotic community underneath the oxidized layer of marine sand bottoms. Mar. Biol. 7: 255-268

Forster, S., Graf, G. (1992). Continuously measured changes in redox potential influenced by oxygen penetrating from burrows of Callianassa subterranea. Hydrobiologia 235/236: $527-532$

Henriksson, R. (1969). Influence of pollution on the bottom fauna of the Sound (Öresund). Oikos 20: 507-523

Jorgensen, B. B. (1980). Seasonal oxygen depletion in the bottom waters of a Danish fjord and its effect on the benthic community. Oikos 34:68-76

Kanneworff, E., Nicolaisen, W. (1973). The 'HAPS' A framesupported bottom corer. Ophelia 10: 119-128

Llanso', R. J. (1992a). Effects of hypoxia on estuarine benthos: the lower Rappahannock River (Chesapeake Bay), a case study. Estuar. coast. Shelf Sci. 35: 491-515

Llanso', R. J. (1992b). Tolerance of low dissolved oxygen and hydrogen sulfide by the polychaete Streblospio benedicti (Webster). J. exp. mar. Biol. Ecol. 153: 165-178

Meyers, M. B., Powell, E. N., Fossing, H. (1988). Movement of oxybiotic and thiobiotic meiofauna in response to changes in pore-water oxygen and sulfide gradients around macroinfaunal tubes. Mar. Biol. 98: 395-414

Miron, G., Kristensen, E. (1993). Behavioural response of three nereid polychaetes to injection of sulfide inside burrows. Mar. Ecol. Prog. Ser. 101: 147-155

Nicolaidou, A. (1983). Life history and productivity of Pectinaria koreni Malmgren (Polychaeta). Estuar. coast. Shelf Sci. $17: 31-43$
Ockelmann, K. W., Muus, K. (1978). The biology, ecology and behaviour of the bivalve, Mysella bidentata. Ophelia 17 $1-93$

Officer, C. B., Biggs, R. B., Taft, J L., Cronin, L. E., Tyler, M. A., Boynton, W. R. (1984). Chesapeake Bay anoxia: origin, development, and significance. Science 223: 22-27

Pearson, T H., Rosenberg, R. (1978). Macrobenthic succession in relation to organic enrichment and pollution of the marine environment. Oceanogr. mar Biol. A. Rev. 16: $229-311$

Pearson, T H., Stanley, S. O. (1979). Comparative measurement of the redox potentral of marine sediments as a rapid means of assessing the effect of organic pollution. Mar Biol. 53: 371-379

Revsbech, N. P., Jorgensen, B. B. (1986). Microelectrodes; their use in microbial ecology. Adv. microb. Ecol. 9: 293-352

Revsbech, N. P., Sørensen, J., Blackburn, T H. (1980). Distribution of oxygen in marine sediments measured with microelectrodes. Limnol. Oceanogr. 25: 403-411

Rosenberg, R. (1977). Benthic macrofaunal dynamics, production, and dispersion in an oxygen-deficient estuary of west Sweden. J. exp. mar. Biol. Ecol. 26: 107-133

Rosenberg, R. (1985). Eutrophication - the future marine coastal nuisance? Mar. Pollut. Bull. 16: 227-231

Rosenberg, R., Elmgren, R., Fleisher, S., Jonsson, P., Persson, G., Dahlin, H. (1990). Marine eutrophication case studies in Sweden - a synopsis. Ambio 19: 102-108

Rosenberg, R., Hellman, B., Johansson, B. (1991). Hypoxic tolerance of marine benthic fauna. Mar Ecol. Prog. Ser. 79 : $127-131$

Rosenberg, R., Loo, L. O. (1988). Marine eutrophication induced oxygen deficiency: effects on soft bottom fauna, western Sweden. Ophelia 29: 213-225

Rosenberg, R., Loo, L.-O., Möller, P. (1992). Hypoxia, salinity and temperature as structuring factors for marine benthic communities in a eutrophic area. Neth. J. Sea Res. 30: $121-129$

Rosenberg, R., Olsson, l., Ölundh, E. (1977). Energy flow model of an oxygen-deficient estuary on the Swedish west coast. Mar. Biol. 42: 99-107

Schöttler, U. (1982). An investigation on the anaerobic metabolism of Nephtys hombergii (Annelida: Polychaeta). Mar. Biol. 71: 265-269

Shick, J. M. (1976). Physiology and behavioural responses to hypoxia and hydrogen sulfide in the infaunal asteroid Ctenodiscus crispatus. Mar. Biol. 37: 279-289

Snedecor, G. W., Cochran, W. G. (1967). Statistical methods, 6 th edn. University of Iowa Press, Ames

Theede, H., Ponat, A., Hiroki, K., Schliper, C. (1969). Studies on the resistance of marine bottom invertebrates to oxygen deficiency and hydrogen sulphide. Mar. Biol. 2: 325-337

Theede, H., Scaudinn, J., Saffé, F. (1973). Ecophysiological studies on four Nereis species of the Kiel bay. Oikos (Suppl.) 15: 246-252

Underwood, A. J. (1981). Techniques of analysis of variance in experimental marine biology and ecology. Oceanogr. mar. Biol. A. Rev. 19: 513-605

Vismann, B. (1990). Sulfide detoxification and tolerance in Nereis (Hediste) diversicolor and Nereis (Neanthes) virens (Annelida: Polychaeta). Mar. Ecol. Prog. Ser. 59: 229-238

Vismann, B. (1991). Sulfide tolerance: physiological mechanisms and ecological implications. Ophelia 34: 1-27

Manuscript first received: April 5, 1994

Revised version accepted: September 21, 1994 